\title{
Tomato yellow leaf curl virus Resistant Tomatoes Show Resistance to Tomato curly stunt virus
}

Gerhard Pietersen, Research Scientist, ARC-Plant Protection Research Institute, Private Bag X134, Pretoria, 0001 South Africa; and Marie F. Smith, Biometrician, ARC-Biometry Unit, Private Bag X519, Silverton, 0127 South Africa

\begin{abstract}
Pietersen, G., and Smith, M. F. 2002. Tomato yellow leaf curl virus resistant tomatoes show resistance to Tomato curly stunt virus. Plant Dis. 86:528-534.

A new disease of tomatoes (Lycopersicon esculentum) in South Africa has caused severe yield losses. The causative virus, Tomato curly stunt virus (ToCSV) is distantly related to Tomato yellow leaf curl virus (TYLCV). Thirty-two tomato accessions resistant to TYLCV and 8 local cultivars were assessed for their responses to ToCSV infection. Natural infection in a field trial and a screen-house trial with controlled ToCSV-inoculation were conducted. Symptoms were rated using a severity index (SI). Yield parameters were determined in the screenhouse trial to support SI evaluations. Average SI's obtained demonstrate that TYLCV-tolerant tomato accessions, with a few exceptions, have milder symptoms of ToCSV infection than TYLCVsusceptible, sensitive accessions. None of the accessions were immune, with some virus detected in all plants. Yield losses due to ToCSV infection of TYLCV-tolerant tomato accessions were not significant $(P>0.10)$ with some exceptions. However, TYLCV-sensitive accessions and 8 local cultivars had significant $(P<0.10)$ yield losses of 49 to $100 \%$. TYLCV-tolerant cultivars may be useful for control of ToCSV, but require evaluation prior to release or use in breeding programs in South Africa.
\end{abstract}

Additional keywords: begomovirus, Bemesia tabaci, whitefly

A new disease of tomatoes (Lycopersicon esculentum L.) emerged during 1997 and 1998 in South Africa (17). A survey showed that the disease occurred at incidences between 0 and $50 \%$ mainly around the Strydomblok District close to the Mozambique border (17). By March 2000, the disease had spread to the KwaZuluNatal/Swaziland/Mozambique border region, where commercial tomato fields with incidences of $100 \%$ were noted (G. Pietersen, unpublished observations).

The disease is transmitted by Bemesia tabaci biotype $\mathrm{B}$, and is caused by a begomovirus, designated Tomato curly stunt virus (ToCSV) (17). Based on nucleotide sequence (nt) homology within the coat protein gene (GenBank Accession No. AF261885), it is most closely related to South African cassava mosaic virus (77\%) (AF011785), East African cassava mosaic virus (77\%) (AJ006459), and Tomato yellow leaf curl-Israel (TYLCV-Is) (76\%) (X15656) (17).

Tomato yellow leaf curl virus (TYLCV), the causative agent of a serious disease of

Corresponding author: G. Pietersen

E-mail: nipbgp@plant1.agric.za

Accepted for publication 30 November 2001.

Publication no. D-2002-0304-02R

() 2002 The American Phytopathological Society tomato, is well studied. It has been present in Middle East countries for decades and several epidemics of the disease have been recorded (2). In recent years it has spread to western Mediterranean countries, the Caribbean, Mexico, and the southern United States $(4,5,9,10,12,14,18-20)$. A number of control strategies have been devised against the virus disease, none of which are effective individually (11). Generally, integrated control strategies are required to control TYLCV $(2,7,11)$. The relationship between ToCSV and TYLCV suggests that they may share a number of biological properties, and that control strategies useful for TYLCV may also work for ToCSV.

Currently, producers in affected areas of South Africa have controlled the disease by regular, uncoordinated application of various insecticides. By analogy with TYLCV, this is likely to be a short-term solution as whiteflies rapidly develop resistance to insecticides $(3,15)$. Genes that confer tolerance to TYLCV-Is have been identified in various wild relatives of tomato (23) with highly tolerant tomato lines having been developed by breeding $(8,22,24)$. Cultivation of tomatoes with resistance to ToCSV will reduce the insecticide required and increase the likelihood of sustained control.

The aim of this study was to assess whether tomato accessions with resistance to TYLCV also are resistant to ToCSV.
The terms "immune", "resistant", "susceptible", "tolerant", and "sensitive", are used in this study as proposed by Cooper and Jones (4). As the variability of ToCSV in South Africa was not known, a field trial with natural infection by the virus was used as an initial screening system, followed by a screenhouse trial with artificial inoculation of isolated ToCSV and an assessment of some yield parameters.

\section{MATERIALS AND METHODS}

Tomato accessions. Seed of 32 commercial tomato cultivars, hybrids or breeding lines with resistance to TYLCV were obtained. These were not limited to those having acceptable agronomic traits and included plants with different sized and shaped fruits, and determinate or indeterminate growth types. Eight local cultivars also were obtained along with five control cultivars previously reported to be either TYLCV or ToCSV sensitive (Table 1).

Virus source. The ToCSV isolate used in inoculations was collected from an infected tomato plant (Plant Protection Research Institute Accession No. 99/0631) from Onderberg, South Africa and isolated by two serial single-whitefly passages at ARC-Plant Protection Research Institute (PPRI) in Pretoria, South Africa (17). The isolate was shown to consist of only one virus by sequencing a number of clones of polymerase chain reaction (PCR) products (unpublished results). The virus was maintained on cv. Red Khaki tomato in whitefly-proof cages. These were in controlledtemperature growth rooms at 24 to $22^{\circ} \mathrm{C}$ (day/night) under banks of four fluorescent tubes (Osram L36W/77) with a 12-h photoperiod. Virus was maintained, propagated, and used as inoculum in the trials using whitefly-mediated transmission.

Vector and transmission. A nonviruliferous colony of Bemesia tabaci (biotype B) was used for all artificial transmission experiments. The colony was originally established from whiteflies collected in Onderberg tomato fields, tested nonviruliferous, and maintained on cotton (Gossypium hirsutum cv. Sabie or Delta Pine 90) in whitefly-proof cages held at $27^{\circ} \mathrm{C}$ in a quarantine-approved insectary at PPRI.

ToCSV was maintained on cv. Red Khaki. Seed were sown in trays in a whitefly-free greenhouse. Seedlings were transplanted into 7-cm-diameter pots after 21 
days. Three days later, pots were transferred to isolated growth rooms for inoculations. Whiteflies, in leaf cages, were allowed a 24-h acquisition access period on PCR tested, ToCSV-infected Red Khaki source plants inoculated 4 weeks earlier. This was followed by a 24-h inoculation access period on tomato test plants with 10 to 15 whiteflies in a leaf cage per plant. Plants were kept within the containment facilities under artificial light. Plants inoculated with viruliferous whiteflies were tested for virus by PCR 9 weeks following transmission, to confirm infection.

Polymerase chain reaction. To detect ToCSV by PCR, plant material was prepared using the apical leaves of plants squashed directly on dry nylon membrane (Hybond-N, Amersham, Arlington Heights, IL) (1). Small sections $\left(1 \mathrm{~mm}^{2}\right)$ of the squashed area were cut using new sterile scalpel blades and placed directly in labeled PCR tubes. Premixed PCR reaction mixture was aliquoted directly in these tubes. PCR reaction was conducted using specific primers: 5'-TCTGACCCATCG CACGGGT-3' (sense) and 5'-CGCTTCAC AAGAGCCTGCTCC-3' (antisense). The primers were designed to a relatively variable sequence of ToCSV in the coat protein gene following multiple alignment with cognate regions of a number of sequenced, closely related begomoviruses. PCR mixtures $(25 \mu$ total volume) contained: 2.5 $\mathrm{mM} \mathrm{MgCl}_{2}, 77 \mu \mathrm{M}$ dNTP's, buffer [67 $\mathrm{mM}$ Tris- $\mathrm{HCl}\left(\mathrm{pH} 8.8\right.$ at $\left.25^{\circ} \mathrm{C}\right), 16 \mathrm{mM}$ $\left(\mathrm{NH}_{4}\right)_{2} \mathrm{SO}_{4}, \quad 0.01 \%$ Tween-20] (Bioline $\mathrm{NH}_{4}$ buffer, Springfield, $\mathrm{NJ}$ ), each primer at $0.4 \mu \mathrm{M}$ and $0.625 \mathrm{U}$ of Taq DNA polymerase (Bioline Biotaq, Springfield, NJ). Amplification conditions were 35 cycles of melting, annealing, and DNA extension of $1 \mathrm{~min}$ at $92^{\circ} \mathrm{C}, 20 \mathrm{~s}$ at $60^{\circ} \mathrm{C}$, and $30 \mathrm{~s}$ at $72^{\circ} \mathrm{C}$, respectively. Amplified DNA fragments (305 bp) were subjected to electrophoresis in $1 \%$ agarose gels and stained with ethidium bromide in TAE buffer (0.04 M Tris-acetate, 0.001 M EDTA). A 19 to 1,114-bp DNA molecular weight marker (Molecular marker VIII; Roche, Germany) was used as a size standard.

Field trial with natural infection of ToCSV. The field trial was conducted during the summers of 1999 and 2000 in Onderberg, South Africa, in a young mango plantation of a commercial tomato producer who had experienced a high incidence of ToCSV infection during the previous tomato winter production season. Seed of 33 tomato accessions were sown in seedling trays during October 1999, and grown under whitefly-free conditions in glasshouses at ARC-PPRI. Twenty-day-old seedlings were planted into 7 -cm-diameter plastic pots. Following hardening off, plants were transplanted in the field. The 33 accessions were tested in randomized complete-block designs. A single plant of each accession was planted in each of 30 blocks. Two previously observed ToCSV- susceptible cvs. Graziella and Rhodade (G. Pietersen, unpublished) were included in each replicate as controls. Seedlings were planted $0.5 \mathrm{~m}$ apart within a row, $1 \mathrm{~m}$ on either side of a spreader row of cv. Graziella planted one month earlier. The spreader rows were interspersed every 17 $\mathrm{m}$ with transplanted ToCSV symptomatic tomato cv. Daniella from commercial plantings, transplanted one and one-half months earlier. Spread of the ToCSV infection in spreader rows was confirmed using PCR prior to transplanting the test plants. Each group of one spreader row and two experiment rows were separated by a row of young mango trees $1 \mathrm{~m}$ from the experiment rows. No insecticides were applied during the course of the experiment.

Symptoms were monitored every 2 weeks, and the disease incidence and severity monitored. Disease severity was rated following a symptom severity index (SI) scale similar to that of Picó et al. (16) for TYLCV-infected tomatoes, modified to reflect the symptoms of ToCSV: $0=$ no symptoms, $1=$ unsure if abnormalities present are induced by ToCSV, $2=$ moderate symptoms-slight marginal yellowing, leaf curl, and puckering, 3 = severe symptoms-marginal yellowing, leaf curl and puckering, reduction in leaf size, no or only slight stunting of the plant, and $4=$ very severe symptoms-marginal yellowing, leaf curl and puckering, reduction in leaf size, and severe stunting of plants.

Screenhouse trial with experimental transmission of ToCSV. Forty-two tomato accessions were tested along with two ToCSV-sensitive cvs. Graziella and Red Khaki. Eight plants per tomato accession were screened. Virus was transmitted by whiteflies to four seedlings of each tomato accession. Control plants of the same tomato accession were exposed to nonviruliferous whiteflies in mock inoculations. In instances where little or no

Table 1. Tomato accessions assessed in this study

\begin{tabular}{|c|c|c|}
\hline Cultivar & TYLCVa resistant & Origin (parent, gene, seed company or reference ${ }^{b}$ ) \\
\hline Pernod & Tolerant & Zeraim Gedera, Israel \\
\hline Amareto & Tolerant & Zeraim Gedera, Israel \\
\hline P 528 & Tolerant & Petoseed, USA \\
\hline P 477 & Tolerant & Petoseed, USA \\
\hline P 556 & Tolerant & Petoseed, USA \\
\hline P 461 & Tolerant & Petoseed, USA \\
\hline 720 & Untested & Asera, South Africa \\
\hline Nadin & Untested & Asera, South Africa \\
\hline 519 & Untested & Asera, South Africa \\
\hline $\mathrm{T}-49$ & Untested & Asera, South Africa \\
\hline Luna & Untested & Asera, South Africa \\
\hline D-53 & Untested & Asera, South Africa \\
\hline Netta & Untested & Asera, South Africa \\
\hline Liat F1 & Untested & Asera, South Africa \\
\hline DRW 5842 F1 & Tolerant & Lycopersicon chilensis; Ty-1; De Ruiter Seed, Holland \\
\hline Valiente F1 & Tolerant & L. chilensis; Ty-1; De Ruiter Seed, Holland \\
\hline DRW 5833 F1 & Tolerant & L. chilensis; Ty-1; De Ruiter Seed, Holland \\
\hline DRW 5831 F1 & Tolerant & L. chilensis; Ty-1; De Ruiter Seed, Holland \\
\hline DRD 8137 F1 & Tolerant & L. chilensis; Ty-1; De Ruiter Seed, Holland \\
\hline DRD 8019 F1 & Tolerant & L. chilensis; Ty-1; De Ruiter Seed, Holland \\
\hline FLA 456 & Tolerant & LA2779/Tyking, University of Florida \\
\hline FLA 591 & Tolerant & LA1969/Tyking/Fiona, University of Florida \\
\hline FLA 582 & Tolerant & LA1938, University of Florida \\
\hline FLA 565 & Tolerant & L. chilense, LA1932, University of Florida \\
\hline STAR 9006 & Sensitive & Starke Ayres, South Africa \\
\hline Jackal & Tolerant & Sluis \& Groot, Holland \\
\hline Kampala & Tolerant & Western Seed Co., Holland \\
\hline HA3004 & Tolerant & Hazera Seed Co., Israel \\
\hline НА3016 & Tolerant & Hazera Seed Co., Israel \\
\hline HА3017 & Tolerant & Hazera Seed Co., Israel \\
\hline HA3019 & Tolerant & Hazera Seed Co., Israel \\
\hline HА 3022 & Tolerant & Hazera Seed Co., Israel \\
\hline HA3047 & Tolerant & Hazera Seed Co., Israel \\
\hline FAVI 9 & Tolerant & Lycopersicon hirsutum (22) \\
\hline FAVI 13 & Tolerant & L. hirsutum (22) \\
\hline FAVI 15 & Tolerant & L. hirsutum (22) \\
\hline FAVI 17 & Sensitive & L. hirsutum (22) \\
\hline FAVI 18 & Tolerant & L. hirsutum (22) \\
\hline PSR 2407558 & Tolerant & Petoseed, USA \\
\hline PX 43316 & Tolerant & Petoseed, USA \\
\hline PSR 2400288 & Tolerant & Hygrotech Seed Co., South Africa \\
\hline Gempack & Tolerant & Hygrotech Seed Co., South Africa \\
\hline Graziella & Untested $^{\mathrm{c}}$ & Zeraim Gedera, Israel \\
\hline Red Khaki & Untested $^{c}$ & ARC-VOPI, South Africa \\
\hline Rhodade & Untested $^{c}$ & ARC-VOPI, South Africa \\
\hline
\end{tabular}

a Tomato yellow leaf curl virus.

b Some information kept confidential by seed companies.

${ }^{\mathrm{c}}$ Untested for TYLCV, but known to be sensitive to ToCSV. 
infection was obtained for an accession, another 10 plants were inoculated with 25 whiteflies per cage to assess the possibility of immunity to ToCSV. Imidacloprid (Confidor SC350; Bayer, Germany), $100 \mathrm{ml}$ at $0.5 \mathrm{ml} /$ liter was applied as a soil drench to kill the whiteflies. Following this, plants were kept within the containment facilities under artificial light for 3 days then sprayed with a contact insecticide, chlorpyriphos (Chlorpirifos; Efekto, South Africa), before transplanting them in large pots within a whitefly-free screenhouse.

The trial was performed during May to October 2000, in the whitefly-free screenhouse under normal daylight conditions with no temperature control. Temperatures ranged from a minimum of $6^{\circ} \mathrm{C}$ to a maximum of $37^{\circ} \mathrm{C}$ with a daily minimum average of $15^{\circ} \mathrm{C}$ and an average maximum of $32^{\circ} \mathrm{C}$. Relative humidity varied from 20 to $100 \%$.

The plants were placed in four replicated completely randomized blocks. Plants of each accession were planted in paired, ToCSV-inoculated and mock-inoculated rows. Blocks comprised four pairs of rows of 11 tomato accessions each. Paired pots and pots within the row were in direct proximity to each other, whereas rows were spaced $0.4 \mathrm{~m}$ apart. Plants were trellised once they exceeded $0.4 \mathrm{~m}$ in height.

Plants were treated every 5 weeks with imidocloprid to ensure that no opportunistic colonization by whiteflies took place. Plants also were subjected to preventative applications of contact insecticides, miticides, and fungicide at various stages during the trial. Plants were given supplementary nutrients weekly starting at the time of flowering. ToCSV-inoculated plants were tested for virus after 9 weeks. Control plants were tested for virus by PCR at the conclusion of the screenhouse trial. Symptoms were monitored once a week for 12 weeks, and recorded on the symptom scale from 0 to 4 as described above. To confirm SI results, yield parameters were determined by a slight modification of that used by Lapidot et al. (8). Fruit was picked over a 6-week period starting 18 weeks after transplanting. Initially, all mature red fruit was collected twice weekly until all plants of an accession had yielded mature red fruits. All mature and immature fruit was then collected 8 to 12 days later. Plant fresh weight (without roots) was measured for all plants immediately after the final total harvest. Fruits were weighed individually (results not shown). Data of total

Table 2. Tomato accessions ranked by mean symptom severity indices after natural infection with Tomato curly stunt virus in the field ${ }^{\mathrm{a}}$

\begin{tabular}{|c|c|c|c|c|}
\hline Accession & TYLCV $^{\mathrm{b}}$ status & Mean $(n=30)$ & SI shortfall & Significance level \\
\hline DRW 5833 F1 & Tolerant & 0.62 & -0.06 & 0.98 \\
\hline FLA 591 & Tolerant & 0.69 & 0.06 & 0.94 \\
\hline DRW 5842 F1 & Tolerant & 0.73 & 0.10 & 0.92 \\
\hline P 528 & Tolerant & 0.73 & 0.10 & 0.92 \\
\hline DRW 5831 F1 & Tolerant & 0.81 & 0.18 & 0.85 \\
\hline HА3016 & Tolerant & 0.89 & 0.26 & 0.75 \\
\hline Pernod & Tolerant & 0.96 & 0.34 & 0.64 \\
\hline Amareto & Tolerant & 1.15 & 0.52 & 0.32 \\
\hline P 461 & Tolerant & 1.16 & 0.53 & 0.29 \\
\hline НА3017 & Tolerant & 1.17 & 0.54 & 0.28 \\
\hline HA3004 & Tolerant & 1.23 & 0.60 & 0.20 \\
\hline FLA 565 & Tolerant & 1.27 & 0.64 & 0.15 \\
\hline Kampala & Tolerant & 1.27 & 0.65 & 0.15 \\
\hline FLA 456 & Tolerant & 1.34 & 0.71 & 0.09 \\
\hline HА3019 & Tolerant & 1.37 & 0.75 & 0.07 \\
\hline FLA 582 & Tolerant & 1.38 & 0.75 & 0.06 \\
\hline HA3022 & Tolerant & 1.38 & 0.76 & 0.06 \\
\hline P 477 & Tolerant & 1.39 & 0.76 & 0.06 \\
\hline Valiente F1 & Tolerant & 1.44 & 0.82 & 0.04 \\
\hline P 556 & Tolerant & 1.44 & 0.82 & 0.03 \\
\hline Jackal & Tolerant & 1.63 & 1.00 & $<0.01$ \\
\hline DRD 8019 F1 & Tolerant & 1.73 & 1.11 & $<0.01$ \\
\hline DRD 8137 F1 & Tolerant & 1.87 & 1.25 & $<0.01$ \\
\hline Netta & Untested & 1.97 & 1.34 & $<0.01$ \\
\hline HA3047 & Tolerant & 2.06 & 1.43 & $<0.01$ \\
\hline 519 & Untested & 2.52 & 1.89 & $<0.01$ \\
\hline Luna & Untested & 2.53 & 1.91 & $<0.01$ \\
\hline 720 & Untested & 2.55 & 1.93 & $<0.01$ \\
\hline D-53 & Untested & 2.58 & 1.95 & $<0.01$ \\
\hline Liat F1 & Untested & 2.59 & 1.96 & $<0.01$ \\
\hline Nadin & Untested & 2.62 & 2.00 & $<0.01$ \\
\hline STAR 9006 & Sensitive & 2.66 & 2.03 & $<0.01$ \\
\hline T-49 & Untested & 2.67 & 2.04 & $<0.01$ \\
\hline Graziella & Untested & 2.71 & 2.09 & $<0.01$ \\
\hline Rhodade & Untested & 3.02 & 2.40 & $<0.01$ \\
\hline
\end{tabular}

a Statistical significance of shortfalls as per the Gupta and Panachapakesan (6) multiple $t$ distribution test procedure. Standard error of an accession mean $=0.20$. Degrees of freedom for error $=874$. Number of accessions $=35$.

${ }^{\mathrm{b}}$ Tomato yellow leaf curl virus. yield and plant fresh weight (aerial portion) were analyzed.

Data analysis. An analysis of variance (ANOVA) was performed in both trials on SI scores obtained at 2 months posttransplanting to test for difference between accessions. Average symptom scores were used in the multiple $t$ distribution test procedure of Gupta \& Panchapakesan (6) and tomato accessions were ranked from "best" (lowest SI) to "worst" with the associated significance levels of the shortfalls (relative to the "best" accession SI) indicated. Fruit symptoms, marketability, or yield were not determined with the field-trial plants. However in the screenhouse trial, ANOVA was performed and standard errors of means and statistical significance of differences were determined on yield data comparing ToCSV-inoculated and control plants. The relative yield losses were determined as a percentage of the yield of the control plants and the significance level of this determined. ToCSV-inoculated plants in which virus could not be detected by PCR were excluded from the analysis.

\section{RESULTS}

Field trial with natural viral inoculum. Natural spread of ToCSV was confirmed within the susceptible "spreader" rows prior to transplanting the various trial accessions using PCR. Symptom development on the trial plants was scored on four occasions. Some clear differences among tomato accessions were observed in both the onset (results not shown) and the severity of symptoms (symptom severity indices, SI's). Susceptible accessions produced severe symptoms starting as a chlorosis of young leaves, progressing to an upward curling of the leaf margins, reduction in size of leaves, and culminating in severe stunting of plant growth. Some tomato accessions showed only mild chlorosis of young leaves with no further growth abnormalities. Some mild symptoms were difficult to ascribe with certainty to ToCSV infection. ANOVA, adjusted for 112 missing values, showed that the means $(n=30)$ of SI scores on tomato accessions were significantly different $(P<0.001)$. A range of average SI's of 0.6 to 3.0 was obtained when accessions were ranked by the index and the multiple $t$ distribution test procedure applied (6) (Table 2).

An average SI threshold of 2.0 was selected to differentiate between tolerant and sensitive accessions. This represents the average index value above which symptoms were confidently ascribed to ToCSV. Applying this threshold separated all TYLCVtolerant accessions from those of untested status or reported TYLCV sensitivity. Two accessions, HA3047, a TYLCV-tolerant breeding line, and cv. Netta, of untested TYLCV-susceptibility, both rank on the threshold with average SI's of 2.0.

The statistical significance of the shortfall of the average SI's however, suggests 
that some TYLCV-tolerant accessions may not necessarily be useful. The average SI's of accessions that ranked between those of cvs. Jackal and Rhodade (Table 2) had significantly $(P<0.01)$ higher shortfalls relative to DRW 5833 ("most tolerant accession") and cluster in the same group as the two sensitive cvs. Graziella and Rhodade. All these accessions were therefore considered sensitive. These included DRD 8019 F1, DRD 8137 F1, and HA3047, which contain genes for TYLCV tolerance. The shortfalls of Valiente F1 and P 556 were higher $(P<0.05)$ than DRW 5833, but did not differ to the same extent as the accessions between cvs. Jackal and Rhodade (Table 2), and therefore, formed an intermediate class of disease sensitivity. Accessions that had average SI shortfalls not significantly higher $(P<0.05)$ than the most tolerant accession were considered clearly tolerant. These were the accessions ranking between DRW5833 F1 hybrid ("most tolerant accession") and P 477 (Table 2). The disease symptoms were milder in these accessions than the sensitive group. PCR analysis of all the plants from three replicates yielded a ToCSV infection rate of $82 \%$. The infection rate within the sensitive controls, which was based on these three replicates, was $86 \%$. None of the accessions tested were free of ToCSV infection in all three replicates. Therefore, none of the cultivars were immune to ToCSV.

Screenhouse trial with ToCSV transmission. In the screenhouse trial, PCR analysis of all ToCSV-inoculated plants indicated an infection rate of $77 \%$. Plants testing negative were retested. In two accessions, HA3047 and FLA 456, all inoculated replicates were free of virus, and in another four accessions (P 461, HA3019, FAVI 15, and FAVI 18) three of the four inoculated plants were not infected. To determine whether these represented escapes from infection, immunity to infection by ToCSV, or unstable genetic lines with segregation of resistance, another 10 plants of each tomato accession were inoculated using 25 whiteflies per plant and tested for ToCSV by PCR. As the majority of these plants were infected (results not shown), it was concluded that none of these accessions were immune to ToCSV and that the ToCSV negative plants in the trial represented escapes. Data of these tomato accessions were excluded from further analysis.

ANOVA on the SI data $(n=4)$, adjusted for a single missing value, showed that tomato accessions were significantly different $(P<0.001)$ with regard to symptoms. As in the field trial, a range of symptoms were observed from very severe to no detectable symptoms (average SI's from 0.0 to 4.0 ) (Table 3 ).

A threshold of 2.0 for the average SI, as applied in the field trial, clearly separated the tomato accessions with TYLCV- resistance (all those above 519 in Table 3) from those reported to be sensitive to TYLCV, or untested TYLCV tolerance. An exception was cv. Kampala, which is TYLCV tolerant. This threshold also coincides with the threshold above which tomato accessions had shortfalls significantly $(P<0.05)$ different from the most tolerant accessions (P 477 in the screenhouse trial) and included sensitive control cvs. Graziella, Red Khaki, FAVI 17, and Star9006.

The growth parameters of ToCSVinfected plants and healthy controls determined in the screenhouse trial are presented in Table 4, and serve to confirm the SI determinations, rather than to evaluate individual cultivars. The yield of TYLCVsensitive tomato cultivars (Star9006 and FAVI 17), was severely affected by ToCSV under the inoculation conditions employed. These two cultivars had significant $(P<$ $0.10)$ reductions in total fruit weight per plant of 97 and $100 \%$, respectively, when infected by ToCSV. Tomato accessions submitted for the trial with an untested TYLCV resistance status (720, Nadin, 519, T-49, Luna, D-53, Netta, and LIAT F1) also all had yield reductions ranging between 48 and $100 \%$. These reductions were all significant at $P<0.10$. The two cultivars, previously observed to be ToCSV sensitive (Graziella and Red Khaki), did not appear to be the most sensitive cultivars among those tested. Fresh plant weight losses varied between 22 and 57\% (not always significant at $P<0.10$ ) for cultivars not previously tested for TYLCV resistance, compared to the 57 and $51 \%$ respective fresh weight losses of the TYLCV-sensitive cvs. FAVI 17 and Star9006.

Yield differences between ToCSVinfected and healthy plants of tomato accessions with tolerance genes to TYLCV were generally not significant $(\mathrm{P}>0.10)$. Some exceptions however were observed. Kampala, which is TYLCV tolerant, showed significant $(P=0.01)$ reduction in total fruit weight $(60 \%)$, as well as the

Table 3. Tomato accessions ranked by mean symptom severity indices after inoculation with Tomato curly stunt virus ${ }^{\mathrm{a}}$

\begin{tabular}{|c|c|c|c|}
\hline Cultivar & TYLCV ${ }^{\mathbf{b}}$ status & Mean SI $(n=4)$ & Significance and shortfall level ${ }^{\mathrm{c}}$ \\
\hline P 477 & Tolerant & 0 & 0.98 \\
\hline P 556 & Tolerant & 0 & 0.98 \\
\hline Valiente F1 & Tolerant & 0 & 0.98 \\
\hline FLA 582 & Tolerant & 0 & 0.98 \\
\hline HA3016 & Tolerant & 0 & 0.98 \\
\hline Favi 9 & Tolerant & 0 & 0.98 \\
\hline FLA 565 & Tolerant & 0.02 & 0.97 \\
\hline HA3017 & Tolerant & 0.09 & 0.96 \\
\hline DRW 5831 F1 & Tolerant & 0.09 & 0.96 \\
\hline DRW 5842 F1 & Tolerant & 0.10 & 0.96 \\
\hline Gempack & Tolerant & 0.10 & 0.96 \\
\hline DRW 5833 F1 & Tolerant & 0.25 & 0.91 \\
\hline HA3004 & Tolerant & 0.25 & 0.91 \\
\hline PSR 2400288 & Tolerant & 0.35 & 0.86 \\
\hline Favi 13 & Tolerant & 0.42 & 0.82 \\
\hline Pernod & Tolerant & 0.50 & 0.77 \\
\hline HA3022 & Tolerant & 0.50 & 0.77 \\
\hline PSR 2407558 & Tolerant & 0.68 & 0.61 \\
\hline PX 43316 & Tolerant & 0.75 & 0.55 \\
\hline DRD 8137 F1 & Tolerant & 0.75 & 0.55 \\
\hline Amareto & Tolerant & 0.75 & 0.55 \\
\hline P 528 & Tolerant & 1.00 & 0.31 \\
\hline FLA 591 & Tolerant & 1.16 & 0.20 \\
\hline Favi 15 & Tolerant & 1.41 & 0.07 \\
\hline DRD 8019 F1 & Tolerant & 1.42 & 0.07 \\
\hline Jackal & Tolerant & 1.50 & 0.05 \\
\hline 519 & Untested & 2.64 & $<0.01$ \\
\hline Graziella & Untested & 2.99 & $<0.01$ \\
\hline 720 & Untested & 3.25 & $<0.01$ \\
\hline Kampala & Tolerant & 3.25 & $<0.01$ \\
\hline Netta & Untested & 3.25 & $<0.01$ \\
\hline Liat F1 & Untested & 3.50 & $<0.01$ \\
\hline Red Khaki & Untested & 3.58 & $<0.01$ \\
\hline Nadin & Untested & 3.75 & $<0.01$ \\
\hline D-53 & Untested & 3.75 & $<0.01$ \\
\hline Star9006 & Sensitive & 3.98 & $<0.01$ \\
\hline Luna & Untested & 4.00 & $<0.01$ \\
\hline Favi 17 & Sensitive & 4.00 & $<0.01$ \\
\hline $\mathrm{T}-49$ & Untested & 4.00 & $<0.01$ \\
\hline
\end{tabular}

a Statistical significance of shortfalls as per the Gupta and Panachapakesan (6) multiple $t$ distribution test procedure.

b Tomato yellow leaf curl virus.

c Mean and shortfall figures the same in this instance. Standard error of an accession mean $=0.37$. Degrees of freedom for error $=89$. Number of accessions $=39$. 
Table 4. Effect of Tomato curly stunt virus (ToCSV) on yield components of tomato accessions grown in a greenhouse

\begin{tabular}{|c|c|c|c|c|c|c|c|c|c|c|}
\hline \multirow{2}{*}{$\begin{array}{l}\text { TYLCVa } \\
\text { Tolerance }\end{array}$} & \multirow[b]{2}{*}{ Plant cultivar } & \multirow{2}{*}{$\begin{array}{l}\text { ToCSV } \\
\text { status }\end{array}$} & \multicolumn{4}{|c|}{ Total yield/plant } & \multicolumn{4}{|c|}{ Plant fresh weight } \\
\hline & & & Av wt (g) & $\%$ Loss & Probability & SE of mean & Av fresh wt (g) & $\%$ Loss & Probability & SE of mean \\
\hline Untested & 519 & Infected & 239.0 & 69.2 & 0.06 & 99 & 332.0 & 21.5 & 0.08 & 24.8 \\
\hline & & Healthy & 776.3 & & & & 423.0 & & & \\
\hline & 720 & Infected & 28.9 & 96.3 & $<0.01$ & 72.6 & 285.0 & 40.2 & 0.03 & 35.5 \\
\hline & & Healthy & 791.3 & & & & 476.3 & & & \\
\hline & D-53 & Infected & 0 & 100.0 & $\ldots{ }^{b}$ & 58.3 & 165.0 & 57.4 & 0.04 & 44.3 \\
\hline & & Healthy & 882.4 & & & & 387.5 & & & \\
\hline & Graziella & Infected & 471.0 & 48.8 & 0.20 & 112.5 & 340.0 & 28.4 & 0.3 & 60.0 \\
\hline & & Healthy & 920.3 & & & & 475.0 & & & \\
\hline & Liat F1 & Infected & 53.1 & 94.6 & 0.03 & 27.8 & 250.0 & 29.3 & 0.19 & 43.1 \\
\hline & & Healthy & 983.9 & & & & 353.8 & & & \\
\hline & Luna & Infected & 510.3 & 56.0 & 0.05 & 112.8 & 221.3 & 50.6 & 0.08 & 59.9 \\
\hline & & Healthy & $1,160.5$ & & & & 447.5 & & & \\
\hline & Nadin & Infected & 144.1 & 81.2 & $<0.01$ & 4.23 & 255.0 & 37.0 & 0.24 & 71.7 \\
\hline & & Healthy & 765.7 & & & & 405.0 & & & \\
\hline & Netta & Infected & 348.1 & 57.1 & 0.01 & 40.5 & 342.0 & 22.1 & 0.07 & 14.8 \\
\hline & & Healthy & 811.2 & & & & 438.8 & & & \\
\hline & Red Khaki & Infected & 105.5 & 77.8 & 0.37 & 119.1 & 428.0 & 20.2 & 0.43 & 75.1 \\
\hline & & Healthy & 475.0 & & & & 536.3 & & & \\
\hline & $\mathrm{T}-49$ & Infected & 0 & 100.0 & $\ldots{ }^{b}$ & & 263.0 & 41.7 & 0.27 & 77.0 \\
\hline & & Healthy & 867.6 & & & & 451.3 & & & \\
\hline Sensitive & FAVI 17 & Infected & 26.8 & 97.1 & $<0.01$ & 84.7 & 176.3 & 57.3 & 0.01 & 29.1 \\
\hline & & Healthy & 936.1 & & & & 412.5 & & & \\
\hline & STAR 9006 & Infected & 0 & 100.0 & $\ldots{ }^{b}$ & & 263.8 & 51.2 & 0.12 & 82.9 \\
\hline & & Healthy & 889.8 & & & & 540.0 & & & \\
\hline Tolerant & Amareto & Infected & 686.3 & $-5.3^{c}$ & 0.61 & 43.6 & 435.0 & -5.8 & 0.71 & 40.6 \\
\hline & & Healthy & 651.5 & & & & 411.3 & & & \\
\hline & DRD 8019 F1 & Infected & 736.6 & -8.4 & 0.87 & 192.8 & 497.0 & -7.2 & 0.23 & 21.4 \\
\hline & & Healthy & 679.7 & & & & 463.8 & & & \\
\hline & DRD 8137 F1 & Infected & 784.1 & 23.5 & 0.05 & 52.1 & 400.0 & 14.7 & 0.19 & 28.4 \\
\hline & & Healthy & $1,024.3$ & & & & 468.8 & & & \\
\hline & DRW 5831 F1 & Infected & 938.5 & -8.7 & 0.52 & 76.7 & 421.3 & 15.3 & 0.4 & 68.4 \\
\hline & & Healthy & 863.1 & & & & 497.5 & & & \\
\hline & DRW 5833 F1 & Infected & 974.9 & 0.8 & 0.30 & 55.6 & 437.0 & -18.5 & 0.08 & 12.03 \\
\hline & & Healthy & 982.9 & & & & 368.8 & & & \\
\hline & DRW 5842 F1 & Infected & 724.6 & 4.7 & 0.67 & 16.5 & 449.0 & -3.0 & 0.81 & 28.8 \\
\hline & & Healthy & 760.2 & & & & 436.0 & & & \\
\hline & FAVI 13 & Infected & 847.9 & -5.9 & 0.19 & 22.5 & 453.0 & -2.3 & 0.58 & 11.25 \\
\hline & & Healthy & 800.7 & & & & 443.0 & & & \\
\hline & FAVI 9 & Infected & 961.6 & -4.2 & 0.10 & 19.3 & 490.0 & -16.1 & 0.31 & 26.5 \\
\hline & & Healthy & 923.2 & & & & 422.0 & & & \\
\hline & Gempack & Infected & 362.0 & 22.8 & 0.15 & 21.4 & 400.0 & 1.8 & 0.87 & 26.3 \\
\hline & & Healthy & 469.2 & & & & 407.5 & & & \\
\hline & Jackal & Infected & 755.1 & 16.6 & 0.25 & 74.7 & 407.5 & -0.3 & 0.97 & 22.3 \\
\hline & & Healthy & 905.6 & & & & 406.3 & & & \\
\hline & Kampala & Infected & 357.0 & 59.9 & 0.01 & 47.2 & 362.5 & 23.7 & 0.06 & 26.4 \\
\hline & & Healthy & 889.8 & & & & 475.0 & & & \\
\hline & HA3004 & Infected & 894.3 & -16.2 & 0.11 & 38.7 & 423.8 & -1.2 & 0.86 & 17.9 \\
\hline & & Healthy & 769.3 & & & & 418.8 & & & \\
\hline & HA3016 & Infected & 992.7 & -1.5 & 0.93 & 108.3 & 345.0 & 14.6 & 0.26 & 30.3 \\
\hline & & Healthy & 978.4 & & & & 403.8 & & & \\
\hline & HA3017 & Infected & 810.9 & 6.2 & 0.80 & 104.1 & 403.0 & 2.6 & 0.65 & 13.35 \\
\hline & & Healthy & 864.1 & & & & 413.8 & & & \\
\hline & HA3022 & Infected & 973.9 & 2.4 & 0.83 & 69.3 & 416.3 & -10.6 & 0.13 & 13.84 \\
\hline & & Healthy & 997.6 & & & & 376.3 & & & \\
\hline & P 477 & Infected & 923.5 & 3.4 & 0.71 & 56.3 & 495.0 & -12.5 & 0.43 & 43.2 \\
\hline & & Healthy & 955.7 & & & & 440.0 & & & \\
\hline & P 528 & Infected & 759.9 & 29.8 & 0.18 & 131.3 & 462.5 & -4.2 & 0.39 & 13.8 \\
\hline & & Healthy & $1,082.8$ & & & & 443.8 & & & \\
\hline & P 556 & Infected & $1,030.2$ & -19.6 & 0.35 & 95 & 473.0 & -0.0 & 0.84 & 26.1 \\
\hline & & Healthy & 861.4 & & & & 430.0 & & & \\
\hline & Pernod & Infected & 718.8 & 6.9 & 0.69 & 85.7 & 412.5 & 15.8 & 0.04 & 16.0 \\
\hline & & Healthy & 771.7 & & & & 490.0 & & & \\
\hline & PSR 2400288 & Infected & 836.1 & -21.8 & 0.34 & 127.7 & 428.0 & -0.9 & 0.94 & 33.9 \\
\hline & & Healthy & 686.6 & & & & 424.0 & & & \\
\hline & PSR 2407558 & Infected & 584.5 & 19.0 & 0.02 & 17.4 & 427.0 & -1.4 & 0.99 & 5.3 \\
\hline & & Healthy & 721.5 & & & & 421.3 & & & \\
\hline & PX 43316 & Infected & 698.2 & -49.8 & 0.07 & 60.3 & 361.3 & -6.3 & 0.18 & 8.71 \\
\hline & & Healthy & 466.1 & & & & 340.0 & & & \\
\hline & FLA 591 & Infected & 645.0 & 0.7 & 0.71 & 103.9 & 473.0 & 3.5 & 0.74 & 76.3 \\
\hline & & Healthy & 649.6 & & & & 490.0 & & & \\
\hline & FLA 582 & Infected & 249.7 & 43.4 & 0.17 & 33.2 & 461.0 & 5.1 & 0.64 & 27.5 \\
\hline & & Healthy & 441.3 & & & & 486.0 & & & \\
\hline & FLA 565 & Infected & 387.3 & 13.8 & 0.51 & 106.2 & 492.0 & -2.8 & 0.97 & 26.8 \\
\hline & & Healthy & 449.2 & & & & 478.8 & & & \\
\hline & Valiente F1 & Infected & 713.5 & -2.2 & 0.58 & 51.1 & 475.0 & 8.7 & 0.11 & 17.0 \\
\hline & & Healthy & 698.0 & & & & 520.0 & & & \\
\hline
\end{tabular}

a Tomato yellow leaf curl virus.

b Cannot determine significance due to total yield loss in infected plants.

${ }^{c}$ A negative sign indicates a relative increase in yield compared to the noninfected control. 
plant fresh weight $(24 \%, P=0.06)$ when inoculated with ToCSV. Similarly, accessions DRD $8137 \mathrm{~F} 1$ and PSR 2407558 also exhibited significant reductions $(P<0.10)$ of total fruit yield when infected with ToCSV.

Significant $(P<0.10)$ increased yield in ToCSV-infected PX 43316 plants relative to healthy plants of this accession is probably as a result of large variation due to segregation in this breeding line, and needs further testing, using larger numbers of replicates. Slight yield increases in some TYLCV-tolerant and ToCSV-infected cultivars were not significant $(P<0.01)$.

\section{DISCUSSION}

A number of tomato accessions with TYLCV tolerance were evaluated for their resistance response to ToCSV. Evaluations were performed in a controlled environment with a characterized ToCSV isolate, as well as relying on natural infection in the field. This was done as it is currently not known whether the disease epidemics in Onderberg and Pongola, South Africa, can be ascribed solely to ToCSV or are the result of several begomoviruses, as found with whitefly-induced epidemics elsewhere in areas historically free of the diseases (21). The field trial with natural infection therefore reflects the response of tomato accessions to infection by the virus population in the region. For the field trial relying on natural infection by whiteflies, it was decided not to use noninfected control plants, as this would require the use of insecticides, which would kill vectors and reduce the natural spread of the disease in the trial. Thus no noninoculated control plants were available, relative to which yield losses could be assessed. Furthermore, factors such as differing times of infection of individual plants within a replicate, different extent of infection of replicates, varying vector preferences of different tomato accessions, and the presence of ToCSV variants or other viruses, may have affected results and increased experimental variation. It was therefore necessary to confirm the results of the field trial with a trial in which controlled inoculation was performed with an isolated ToCSV source along with appropriate noninfected controls.

PCR analysis of three replicates within the field trial revealed the presence of ToCSV in plants of all tomato accessions. None were immune to the ToCSV virus population in the area. Furthermore, the absence of accessions with an average SI of 0 in the field as opposed to six cultivars with SI's of 0 in the screenhouse trial when ToCSV inoculation was performed, suggests that other viruses or strains are present. The SI's obtained using natural infection of ToCSV separated accessions with TYLCV resistance from those without this property, and effectively showed that tomatoes containing genes for resistance to
TYLCV could be useful in reducing the yield loss effects by ToCSV. As expected, the variation in SI's within replicates (with no average SI's $=4$ obtained), resulting from reliance on natural infection, did not allow for a clear statistically significant discrimination of some accessions as ToCSV-sensitive or tolerant. The plants within a replicate that lacked symptoms may have been escapes from infection or could have been infected close to the time that final observations were made and disease symptoms had not yet developed.

To confirm the SI evaluations using less subjective parameters, an assessment of the relative response of TYLCV tolerant and sensitive tomato accessions with regard to total yield of fruit, and plant fresh weight (aerial portion) were determined. Yield losses induced by ToCSV on TYLCVtolerant tomato accessions were generally not significant at $P>0.10$ (with a few exceptions), whereas the two TYLCVsusceptible accessions had significant losses of total yield. Accessions of untested TYLCV resistance status all appeared to be sensitive to ToCSV. In order to compare resistance levels among tomato accessions and to accurately assess the yield affect of ToCSV on these, field trials with larger numbers of replicates need to be performed in a manner similar to Lapidot et al. (8).

The ToCSV sensitive response of the cv. Kampala, DRD 8137 F1, and PSR 2407558 (previously tested TYLCV- tolerant accessions), indicates that the yield of TYLCV-tolerant cultivars are not always significantly unaffected by ToCSV. This is a situation analogous to that for TYLCV and the Indian isolate of Tomato leaf curl virus (13). The suitability of new TYLCV tolerant accessions for control of ToCSV in Southern Africa must therefore continue to be assessed prior to commercial application.

The high level of escapes in accessions HA3047, FLA 456, P 461, HA3019, FAVI 15 , and FAVI 18 may represent some resistance to the transmission of the virus by whiteflies rather than to virus replication (13). This would have to be assessed in further experiments.

In conclusion, this study has shown that tomatoes with TYLCV resistance are a good source of genes for resistance to ToCSV, and that such tomatoes could be useful for the control of ToCSV in Southern Africa, reducing the reliance on insecticides. The response of such tomatoes to ToCSV would need to be assessed in detail and resistant types used in local breeding programs to select cultivars with agronomic properties suitable for local conditions.

\section{ACKNOWLEDGMENTS}

We would like to thank J. Maré (Onderberg) for the use of his farm and labor for the field trial, Daniel Montsho and G. G. F. Kasdorf (ARC-PPRI) for their assistance in planting the field trial, E. van der Berg (ARC-Biometry unit) for her assis- tance with the statistical analysis of data, $\mathrm{K}$ Krüger and T. Bird (ARC-PPRI) for assistance with the whitefly transmission, and the Tomato Producers Organization of South Africa for partial funding of the study.

\section{LITERATURE CITED}

1. Atzmon, G., van Oss, H., and Czosnek, H. 1998. PCR-amplification of Tomato yellow leaf curl virus (TYLCV) DNA from squashes of plants and whitefly vectors: Application to the study of TYLCV acquisition and transmission. Eur. J. Plant Pathol. 104:189-194.

2. Cohen, S., and Antignus, Y. 1994. Tomato yellow leaf curl virus, a whitefly-borne geminivirus of tomatoes. Adv. Dis. Vector Res. 10:259-288.

3. Cohen, S., and Melamed-Madjar, V. 1974 Prevention of spread of Tomato yellow leaf curl virus transmitted by Bemesia tabaci in Israel. Bull. Entomol. Res. 64:193-197.

4. Cooper, J. I. and Jones, A. T. 1983. Responses of plants to viruses: Proposals for the use of terms. Phytopathology 73:127-128.

5. González, G., and Valdés, S. 1995. Virus del encrespamiento amarillo de las hojas del tomate (TYLCV) en Cuba. CEIBA (Honduras) 36:103.

6. Gupta, S. S., and Panchapakesan, S. 1979. Multiple decision procedures: theory and methodology of selecting and ranking populations. John Wiley \& Sons, New York.

7. Ioannou, N. 1987. Cultural management of tomato yellow leaf curl disease in Cyprus. Plant Pathol. 36:367-373.

8. Lapidot, M., Friedmann, M., Lachman, O., Yehezkel, A., Nahon, S., Cohen, S., and Pilowsky, M. 1997. Comparison of resistance level to Tomato yellow leaf curl virus among commercial cultivars and breeding lines. Plant Dis. 81:1425-1428.

9. Louro, D., Noris, E., Veratti, F., and Accotto, G. P. 1996. First report of Tomato yellow leaf curl virus in Portugal. Plant Dis. 80:1079.

10. McGlashan, D., Polston, J. E., and Bois, D. 1994. Tomato yellow leaf curl geminivirus in Jamaica. Plant Dis. 78:1219.

11. Nakhla, M. K., and Maxwell, D. P. 1998 Epidemiology and management of tomato yellow leaf curl disease. Pages 565-583 in: Plant Virus Disease Control. A. Hadidi, R. K. Kheterpal, and H. Koganezawa, eds. The American Phytopathological Society, St. Paul, MN.

12. Nakhla, M. K., Maxwell, D. P., Martinez, R. T., Carvalho, M. G., and Gilbertson, R. L. 1994. Occurrence of the eastern Mediterranean strain of tomato yellow leaf curl geminivirus in the Dominican Republic. Phytopathology. 84:1072.

13. Nateshan, H. M., Muniyappa, V., Jalikop, S. H., and Ramappa, H. K. 1996. Resistance of Lycopersicon species and hybrids to tomato leaf curl geminivirus. Pages 369-377 in: $\mathrm{Be}$ misia: 1995 Taxonomy, Biology, Damage, Control and Management. D. Gerling and R. T. Mayer, eds. Intercept Ltd, Andover, UK

14. Navas-Castillo, J., Sánches-Campos, S., Díaz, J. A., Sáez-Alonso, A., and Moriones, E. 1997. First report of Tomato yellow leaf curl virus-IS in Spain: coexistence of two different geminiviruses in the same epidemic outbreak. Plant Dis. 82:1461.

15. Nitzany, F. E. 1975. Tomato yellow leaf curl virus. Phytopathol. Mediterr. 14:127-129.

16. Picó, B., Díez, J., and Nuez, F. 1998. Evaluation of whitefly-mediated inoculation techniques to screen Lycopersicon esculentum and wild relatives for resistance to Tomato yellow leaf curl virus. Euphytica 101:259-271.

17. Pietersen, G., Idris, A. M., Krüger, K., and Brown, J. K. 2000. Tomato curly stunt virus, a new begomovirus of tomato within the To- 
mato yellow leaf curl virus-Is cluster in South Africa. Plant Dis. 84:810.

18. Polston, J. E., and Anderson, P. K. 1997. The emergence of whitefly-transmitted geminiviruses in tomato in the western hemisphere. Plant Dis. 81:1358-1369.

19. Polston, J. E., McGovern, R. J., and Brown, L. G. 1999. Introduction of Tomato yellow leaf curl virus in Florida and implications for the spread of this and other geminiviruses of tomato. Plant Dis. 83:984-988.

20. Ramos, P. L., Guerra, O., Dorestes, V., Rami- rez, N., Rivera-Bustamante, R., and Oramas, P. 1996. Detection of TYLCV in Cuba. Plant Dis. 80:1208.

21. Ribeiro, S. G., de Avila, A. C., and Bezerra, I. C. 1998. Widespread occurrence of tomato geminiviruses in Brazil. Plant Dis. 82:830.

22. Vidavsky, F. and Czosnek, H. 1998. Tomato breeding lines immune and tolerant to Tomato yellow leaf curl virus (TYLCV) issued from Lycopersicon hirsutum. Phytopathology 88:910-914.

23. Zakay, Y., Navot, N., Zeidan, M., Kedar, N.,
Rabinowitch, H. D., Czosnek, H., and Zamir, D. 1991. Screening Lycopersicon accessions for resistance to Tomato yellow leaf curl virus: presence of viral DNA and symptom development. Plant Dis. 75:279-281.

24. Zamir, D., Ekstein-Michelson, I., Zakay, Y. Navot, N., Zeidan, M., Sarfatti, M., Eshed, Y., Harel, E., Pleban, T., Van-Oss, H., Kedar, N., Rabinowitch, H. D., and Czosnek, H. 1994. Mapping and introgression of a Tomato yellow leaf curl virus tolerance gene, TY-1. Theor. Appl. Genet. 88:141-146. 